\title{
MEMOIR
}

\section{ANDREW HERRICK ROWELL}

Sir Andrew Herrick Rowell died on 27 August 1973 in his 84th year. To members of the Institute one tribute overshadows all the rest. He was our Centenary President. It was in June 1948 that the bonds of friendship and affection, so strong among actuaries the world over, but which had been so hard to sustain in the preceding years of war and its aftermath, were gloriously restored with the Centenary Assembly of the Institute of Actuaries in London at which Andrew Rowell, newly knighted by Ilis Majesty, presided so memorably. To his contemporaries the Centenary Assembly was a time for old friends and new resolves. To one young actuary, not yet fully qualified, and he cannot have been alone, it was the kindling of a flame of love of and pride in his profession which still burns brightly today.

What more appropriate tribute to Sir Andrew's presidency could there be than that paid by William Penman, proposing the 'omnibus resolution' at the Annual General Meeting of the Institute at the end of June 1948? 'On the 12th day of March, 1890', he said, 'the Corps of Fairy Godmothers was very busy around a certain cradle and its members were lavish in their gifts. One fairy godmother gave the occupant a good appearance, another a pleasant voice; others gave him an attractive personality, a sense of humour, a kindly wit, the spirit of courtesy, a fluent tongue, firmness of character, tact, an equable disposition and a first-class brain. I do not have to prove the truth of these statements. When applied to our President they are axiomatic.

'But the remainder of the tale is a matter of rumour. It is said that just before dismissing the parade, discipline was relaxed for a moment and the senior fairy godmother was heard to say "Well, girls, if they only have the sense to make use of him, we have provided the Institute of Actuaries with an ideal President for its Centenary Year":'

Mr Penman was not for a moment suggesting that the President's success was due cntircly to the gifts with which he had been so liberally endowed. However gifted a person might be, he had to exercise his gifts before they could be useful, and thanks were due-full measure, pressed down and running over - to the President for the way in which he had placed all his gifts, all his resources and all his energy at their disposal during the past year, and particularly during the centenary celebrations.

Few events, if any, had given more satisfaction to members of the Institute than the knighthood conferred upon the President. It was to the President personally a well-merited and wellearned honour, and to the Institute it was a much-appreciated compliment that His Majesty should so have honoured its President.

Andrew Herrick Rowell was born at Brigstock in Northamptonshire. He was the son of a fellmonger, Jabez Rowell, and his wife Eliza. Four of their children died in infancy. Andrew was the ninth of the eleven who survived, six boys and five girls. He has told some fascinating stories of his childhood, spent, to use his own words, in a wonderful home, headed by a saintly mother and a deeply religious father, devoted to each other.

He has told of a fall, as a small boy, 10 feet on to a brick courtyard on his head, following which he was unconscious for some days. He claimed that he was measured by the local undertaker for his coffin, but eventually recovered, with a permanent dent in his skull, but otherwise intact. He said that his elder brother always attributed any subsequent scholastic success to this fall, which was said to be the making of him.

He has told too how he spent his early years in a fuzzy indistinctness, and how, one day, sitting in the back row at the village school, he complained, when taken to task for some shortcoming, that he could not read what was on the blackboard. It was only then that his considerable short-sightedness was discovered, and remedied by spectacles. From then he never looked back. He went to Wellingborough, won a series of prizes, and left with a County Council scholarship, a school-leaving scholarship and an open scholarship to St John's 
College, Cambridge. At Cambridge he settled for a balanced programme of work and leisure and emerged with Second Class Honours in Parts I and II of the Mathematical Tripos. It was a quarter of a century later, in 1938, that he gave to the writer of this memoir, then about to sit Part II, the memorable advice 'Go back to Cambridge and get a second. Business men are apt to regard a wrangler as a bit out of this world, and a third is not quite as good as it ought to be'. His advice was followed.

After Cambridge, and a short spell with the Commercial Union, he joined the staff of the Clerical, Medical \& General Life Assurance Society in February 1913. He saw service in the First World War with the Royal Engineers, and, on his twenty-eighth birthday, in March 1918, was captured by the enemy near Lille. The discomforts and privations which he suffered as a prisoner of war were considerable, but he returned safely home at the end and rejoined the Clerical Medical. He qualified as a Fellow of the Institute in 1922, became Assistant Actuary in 1923, before succeeding A. D. Besant as General Manager and Actuary in 1933 until his retirement in 1950. Retirement to him was in no way a departure from the scene; it was merely a change of direction. He was appointed to the Society's Board, of which he remained a member until the end of 1969, and of which he was a Deputy Chairman between 1954 and 1966. But freedom from day-to-day responsibilities gave him more time to pursue his other interests, of which he had many.

He continued to serve on a number of other boards, including those of the Employers' Liability Assurance Corporation, of Brixton Estate, Shop Investments and Western Ground Rents among property companies, and of Minerals Separation, later to become Foseco Minsep.

His wisdom in choice of investments will long be remembered. He saw, before many of his contemporaries, that government securities yielding $2 \frac{1}{2} \%$ were liable to depreciate, while ordinary shares, yielding much more, yet looked on 25 years ago with considerable suspicion, were promising and acceptable investments. But it was in the world of property that he became a legend in his own lifetime. He had a genius for discovering, and working with, and guiding, somewhat off-beat characters. There was one, in particular, with more native wit than formal education, who, at an early meeting with him, said, prophetically, 'Do you know, my boy, 1 guess that with your money and my brains we could go places'. He was one of the great pioneers of the use of life assurance funds to finance property development and property companies, and it was fitting that his last contribution to an Institute discussion was on the paper presented in March 1961 by the late E. Kingsley Read on Life Ofice Property Investments. As J.I.A. reporled his closing words; "The pace was hot and it was getting hotter, and in his view it could not possibly be free from danger. Having uttered the word "danger", he supposed that all his remarks would be dismissed as senile pessimism. They were not really. He had always had faith in property - at the right price.'

Andrew Rowell served the Institute as a member of Council for 19 years between 1932 and 1952, as an examiner, as Chairman of the Students Society, as Honorary Secretary, as Vice President, long years of devoted service culminating in the Presidency in 1946-48. He was chairman of the Actuaries Club in 1951-53, and of the Gallio Club in 1936-37.

In all this activity he was supported by his own devoted family. He married, in 1922, Olive Gwendoline Bessie Coles, the sister of one of his Cambridge undergraduate friends. They lived for some years in Golders Green, and in 1932 bought 'Calumet', Beaconsfield. This was to be the family home until Lady Rowell's sudden death in 1956, and it was there that their two children, Jean and Oliver, grew up. It was there too that Sir Andrew was cared for by his daughter and her husband for seventeen more years until his death. Meanwhile, his son and daughter-in-law had presented him with three grandchildren of whon he was most proud.

Sir Arthur Bryant, in 'A History of the British United Provident Association' which marked the twenty-first birthday of the Association in 1968, wrote: "In April 1945 this tireless pioneer (Alderman William Hyde) of Provident Associations died suddenly in his sleep. His mantle fell on an actuary of rare drive and imagination, $\mathrm{Mr}$ (later Sir) Andrew Rowell, the General Manager of Clerical, Medical \& General Life Assurance Society, who a year or so earlier had been sent by the Institute of Actuaries to remonstrate with him for claiming that the Nuffield Provident Guarantee Fund's tables of contributions and benefits were actuarially based, which 
strictly speaking they were not. No more fortunate event for the future of provident insurance could have occurred, for, with his infectious enthusiasm, William Hyde had persuaded this brilliant actuary that the best way to make his Institute's protest effective was to give his services to the Central Provident Association as official consultant on actuarial management. This Rowell agreed to do.... He became a protagonist of a national association of all provident societies operating a united scheme for the whole country, and he was invited to become the first chairman of the resulting British United Provident Association. As the next quarter of a century rolled by, BUPA came closer and closer to his heart. He was tremendously proud of the way in which, under his guidance, BUPA grew from small beginnings to its present standing of an association known and respected not merely in the United Kingdom but in all countries throughout the world where voluntary health service funds exist. In his belief that, if the private sector of medicine was to exist alongside the public sector, it should make its own substantial contribution to the provision of the necessary facilities, he was instrumental, in association with BUPA, in founding Nuffield Nursing Homes Trust, which now owns more than 20 small private hospitals across the country.

Sir Andrew will be remernbered with affection by a host of friends, among whom will be numbered all his former colleagues in all his many activities, for he was a born leader with a gift for friendship, and a brilliant raconteur who could make any social occasion at which he presided memorable.

In July 1973 the Institute celebrated its 125th Anniversary with another Assembly. Geoffrey Heywood, as President, wrote to Sir Andrew inviting him to be present at one at least of the functions. Sir Andrew wrote back, in that beautiful copperplate handwriting which his friends knew so well and which he retained to the end. The exchange of messages was read out at the opening meeting of the 125th Anniversary Assembly in Staple Inn. It was fitting that Andrew Rowell, in the late evening of his life, and some years after his last personal appearance at an actuarial occasion, should send us this message of his own faith in the future of his profession and ours.

L. G, HALL L 